\title{
SUKCESJA POKOLENIOWA ZARZACDU PRZEDSIĘBIORSTWA W KONTEKŚCIE CSR. WYNIKI BADAŃ EMPIRYCZNYCH W WOJEWÓDZTWIE MAZOWIECKIM
}

DOI: 10.33141/po.2020.01.07

\section{Aleksandra Zaleśna}

\section{Wprowadzenie}

W niniejszym artykule łączy się problematykę społecznej odpowiedzialności przedsiębiorstwa (corporate social responsibility, CSR) z zagadnieniem sukcesji na stanowisku prezesa. Według K. Basu i G. Palazzo (2008, s. 124), na społeczną odpowiedzialność organizacji należy spojrzeć przez pryzmat tego, co na ten temat myślą i mówią menedżerowie. W odpowiedzialnych i zrównoważonych przedsiębiorstwach, jak donoszą A. Rego i inni (2017) na podstawie wywiadów z 72 prezesami z przedsiębiorstw w Portugalii, zadaniem prezesa jest m.in. przygotowanie następcy. Według wypowiedzi jednego z nich, „przywódca musi zacząć myśleć, jak organizacja będzie żyła bez niego" (Rego i in., 2017, s. 145). Prezes organizacji ma wgląd w proces rozwoju liderów i może identyfikować obiecujących kandydatów na sukcesorów (Berns, Klarner, 2017, s. 90-91).

Proces sukcesji to zagadnienie mało przebadane (Berns, Klarner, 2017, s. 83-84), w kontekście CSR takich badań jest jeszcze mniej. W badaniu K. Szczepańskiej-Woszczyny (2018, s. 15) można znaleźć pewne elementy nawiązujące do idei CSR i problemu sukcesji w firmach rodzinnych, jak na przykład „uczciwość wobec interesariuszy”, która stanowi wartość dla blisko $17 \%$ właścicieli firm rodzinnych i 17\% sukcesorów. Problem jest wart badania, zwłaszcza że „rola CSR w UE będzie rosła” (Kudłak, 2017, s. 77). Pojawia się pytanie badawcze: czy top menedżerowie oraz założyciele (właściciele) przedsiębiorstw przygotowują następcę, który będzie kontynuował realizację idei CSR?

\section{Sukcesja prezesa i obawy interesariuszy}

S ukcesja to proces przygotowania następcy do przejęcia nowej roli, do przejęcia biznesu, podejmowany celem zapewnienia ciągłości przywództwa na kluczowych stanowiskach w organizacji (Bohdziewicz, 2014, s. 46-47; Sułkowski, 2012, s. 465). Jest to proces o istotnym znaczeniu, 
gdyż od tego zależy jakość kadr na kluczowych stanowiskach w organizacji (Bohdziewicz, 2014, s. 45). Proces planowania sukcesji na stanowiska kierownicze ma zapewnić rozwój umiejętności menedżerskich w relacji do celów organizacji, a nie jedynie celów danego działu (Rothwell, 2010, s. 6).

Sukcesja ma miejsce w różnego rodzaju organizacjach, jak np. w przedsiębiorstwach rodzinnych ${ }^{1}$ (Sułkowski, 2012, s. 463), organizacjach pozarządowych (Reichel, 2018, s. 9), w spółkach notowanych na giełdzie ${ }^{2}$. W polskich warunkach, w spółkach publicznych na rynku kapitałowym, jedynie w $11,41 \%$ przypadków nowych powołań $(\mathrm{n}=885)$ sukcesję można uznać za zaplanowaną (Byrka-Kita i in., 2018, s. 24-25).

Problem sukcesji na stanowisku dyrektora naczelnego/ prezesa jest ważny także z punktu widzenia poszczególnych interesariuszy organizacji, tj. pracowników, klientów, dostawców, społeczności lokalnej itp. W świetle teorii interesariuszy przedsiębiorstwo stanowi współwłasność społeczeństwa $^{3}$ (Zbierowski, 2014, s. 12). Zbliżanie się do wieku emerytalnego obecnego prezesa może rodzić wśród pracowników obawy, jaki będzie ich nowy szef, jaką będzie stosował wobec nich politykę zatrudnienia. Wśród dostawców również mogą pojawić się obawy o dalsze warunki współpracy z przedsiębiorstwem. Podobne obawy mogą żywić klienci przedsiębiorstwa. Chociaż nie mają oni wpływu na przebieg procesu sukcesji, to chcą dbać o własne interesy. Przykładowo klienci firmy Comarch, chcąc mieć zapewnioną ciągłość dostaw produktów i usług, wpisują „do kontraktów kary umowne za zmianę kontroli właścicielskiej” (Janoś, 2017). Brak sukcesji i sprzedaż przedsiębiorstw innym właścicielom może wywołać niezadowolenie wśród klientów. Tak było na przykład, gdy Anita Roddick, założycielka sieci sklepów The Body Shop, w 2006 r. sprzedała firmę koncernowi L’Oreal. Tym faktem wielu klientów etycznie nastawionych było oburzonych (Cahalane, 2006). Także organizacje pozarządowe funkcjonujące $\mathrm{w}$ danej społeczności lokalnej mogą nie być pewne wsparcia finansowego i rzeczowego po zmianie osoby na stanowisku prezesa. Przykładowo Steve Jobs po powrocie do firmy Apple w 1997 r. zlikwidował programy wsparcia organizacji charytatywnych (Tang i in., 2015).

Prawidłowo przeprowadzona sukcesja jest procesem wieloletnim, dobrze zaplanowanym i ciągłym (Berns, Klarner, 2017 , s. 84 ). Nie jest to pojedyncze wydarzenie polegające na zmianie osoby zarządzającej przedsiębiorstwem. Przykładowo, w przedsiębiorstwie General Electric (amerykański koncern notowany na giełdzie) pod kierownictwem Jacka Welcha, przy współudziale rady dyrektorów, proces sukcesji trwał 7 lat (Berns, Klaner, s. 83-84).

Zamiast przygotowania następcy można podjąć decyzję o zatrudnieniu na stanowisko prezesa nowej osoby. Jednym z dylematów związanych z dokonaniem sukcesji stanowiskowej jest rozstrzygnięcie, czy właściwych kandydatów należy szukać wewnątrz czy na zewnątrz przedsiębiorstwa (Bohdziewicz, 2014, s. 48). Jednak pozyskanie kandydata na stanowisko prezesa nie zawsze przynosi organizacji pozytywne efekty. Bywa, że zatrudnienie osoby mającej doświadczenie menedżerskie na stanowisku prezesa $\mathrm{w}$ przedsiębiorstwie o podobnej wielkości nie gwarantuje dalszego powodzenia przedsiębiorstwa (Hamori, Koyuncu, 2015, s. 36). Dlatego warto pomyśleć o sukcesji, tj. o przygotowaniu własnego następcy na stanowisko prezesa organizacji.

Przytoczone powyżej przykłady pokazują, że problem sukcesji można i należy rozpatrywać także z punktu widzenia realizacji przez przedsiębiorstwo koncepcji CSR. Pokazują to badania A. Rego i innych (2017). Problem również dostrzega wielu badaczy. A. Lindgreen i inni (2012) podjęli badania (studia przypadków) w przedsiębiorstwach należących do sieci organizacji społecznie odpowiedzialnych. Odkryli oni jednak, że w praktyce brakuje systematycznego podejścia do kształtowania następców i rozwoju ich kompetencji w kontekście CSR (Lindgreen i in., 2012, s. 82).

\section{Metoda badawcza}

W poszukiwaniu odpowiedzi na pytanie badawcze przyjęto metodę sondażu diagnostycznego (Apanowicz, 2002, s. 70). Studia przypadków jako metoda badań, którą obrali wspomniani A. Lindgreen i inni (2012), nie pozwalają ocenić skali występowania zjawiska. Sondaż pozwoli na dokonanie takiej oceny (Apanowicz, 2002, s. 71). Ponadto prezesi stanowią grupę osób mocno zaabsorbowanych pracą. Dlatego też pod względem ilości czasu poświęconego na badanie bardziej dogodnym dla nich narzędziem badawczym jest kwestionariusz ankiety niż wywiad ustny (Witaszek, 2007, s. 149). Kwestionariusz ankiety pozwala ponadto dotrzeć do osób „rozproszonych na szerokim obszarze geograficznym” (Frankfort-Nachmias, Nachmias, 2001, s. 261).

W badaniu udział wzięli prezesi/dyrektorzy generalni z przedsiębiorstw średniej i dużej wielkości, z sektora prywatnego, zlokalizowanych w województwie mazowieckim. Celem zwiększenia prawdopodobieństwa występowania $\mathrm{w}$ przedsiębiorstwie procesu przygotowania sukcesji do badań przyjęto przedsiębiorstwa powstałe najpóźniej do $2008 \mathrm{r}$. W istocie są to przedsiębiorstwa produkcyjne $\mathrm{z}$ różnych branż powstałe w latach 1996-2007. Zajmują się one m.in. produkcją wyrobów z drewna, mebli, poligrafią, produkcją wyrobów ze skór, odzieży, wyrobów farmaceutycznych, wyrobów z papieru czy środków chemicznych. Trzy przedsiębiorstwa zajmują się usługami transportowymi (2,5\% ogółu). Dobór przedsiębiorstw do badań podyktowany był wpływem ich działalności na środowisko naturalne. Kwestionariusz ankiety wraz z listem przewodnim skierowano mailowo do prezesów z 2350 przedsiębiorstw (dobór losowy z bazy podmiotów zakupionej przez firmę 0,5 Sigma Research \& Development Mateusz Zych). Uzyskano odpowiedzi od 231 podmiotów (odsetek zwrotności wynosi blisko 10\%). Badanie metodą CAWI (Computer Assisted Web Interview) przeprowadzono na przełomie listopada i grudnia 2018 r. przez firmę 0,5 Sigma Research \& Development Mateusz Zych.

Nie wszyscy spośród badanych prezesów myślą o przeprowadzeniu sukcesji. Na pytanie filtrujące: „Czy przygotowuje Pan/i następcę na swoje stanowisko?”, jedynie 51\% 
z nich odpowiedziało twierdząco. Wyniki badań prezentowane w dalszej części artykułu dotyczą tej grupy respondentów ( $\mathrm{n}=119$ osób).

Wśród badanych prezesów 36,1\% stanowią założyciele (właściciele) przedsiębiorstw (rys. 1). Kobiet jest niewiele - ich udział wynosi 15,9\%. Respondentami są menedżerowie głównie w wieku 46-55 lat i stanowią 57,9\% ogółu. Są również młodsi, tj. w wieku 36-45 lat (20,2\%), a także starsi w wieku powyżej 55 lat $(14,3 \%)$. Niewielki udział stanowią prezesi w wieku 26-35 lat (7,6\%). Dane dotyczące m.in. wieku respondentów prezentuje tabela 1 .

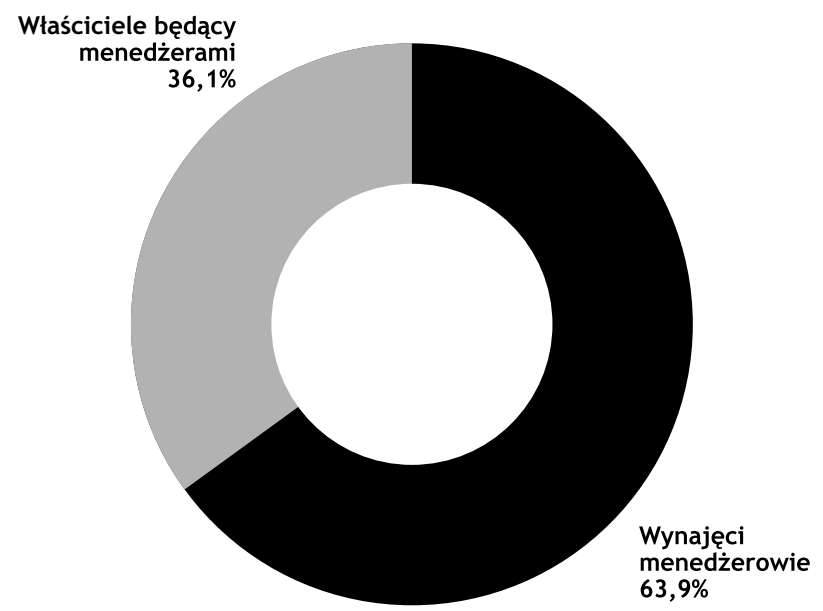

Rys. 1. Rozkład respondentów - wynajęci menedżerowie i właściciele zarządzający przedsiębiorstwem

Źródto: opracowanie wtasne

Wszyscy prezesi posiadają wykształcenie wyższe. $\mathrm{Z}$ uwagi na produkcyjny charakter prowadzonej działalności przez przedsiębiorstwa zdecydowana większość prezesów posiada wykształcenie o profilu technicznym (84,9\%), jedynie $10,0 \%$ posiada wykształcenie ekonomiczne. Pozostała część prezesów posiada wykształcenie o profilu prawniczym lub społecznym (psychologia, socjologia). Co czwarty prezes ukończył ponadto studia podyplomowe, w tym 7,6\% ukończyło studia MBA.

Badani prezesi mają przeważnie długoletni staż pracy na obecnie zajmowanym stanowisku. Staż od 6 do 10 lat posiada $46,2 \%$ osób. Taki sam odsetek zajmuje stanowisko od ponad 10 lat. Jedynie 7,6\% prezesów ma staż 1-5 lat. Od lat są oni związani ze swoim przedsiębiorstwem. Niemal dwie trzecie prezesów ma ponad 10-letni staż pracy
26,9\% z nich ma staż od 6 do 10 lat, staż 3-5 lat pracy posiada 7,6\% menedżerów. W badanej próbie nie było osób o stażu pracy krótszym niż 3 lata i stażu na stanowisku prezesa poniżej roku.

Mogłoby się wydawać, że o sukcesji należy mówić jedynie w odniesieniu do osób w wieku 56 lat i powyżej. Należy jednak podkreślić, że nie chodzi o sam moment sukcesji, lecz o proces jej przygotowania, który powinien być realizowany w sposób systematyczny i długofalowy (Bohdziewicz, 2014, s. 46; Berns, Klarner, 2017, s. 83). Z obserwacji własnych autorki opracowania wynika, że o przygotowaniu sukcesji myślą także młodsi prezesi. Tak się dzieje w niektórych przedsiębiorstwach. Autorce opracowania znane są osobiście dwa takie przypadki. $\mathrm{W}$ jednym $\mathrm{z}$ nich przygotowanie sukcesji wynika $\mathrm{z}$ chęci przekazania władzy młodszej osobie, mającej świeże spojrzenie na biznes, w drugim przypadku - jest praktyką rekomendowaną przez centralę korporacji międzynarodowej. $\mathrm{W}$ obu przypadkach prezesi są $\mathrm{w}$ wieku około 40 lat i zajmują stanowisko od co najmniej 6 lat (tab. 1).

W kwestionariuszu ankiety jako format pytań zastosowano pytania tabelaryczne (Frankfort-Nachmias, Nachmias, 2001, s. 276). Do pomiaru społecznej odpowiedzialności przedsiębiorstw wykorzystano propozycję skali autorstwa D. Turker (2009, s. 422). Do pomiaru ekonomicznego wymiaru CSR wykorzystano dodatkowo twierdzenia ze skali zaproponowanej przez I. Maignan, O.C. Ferrella i G.T.M. Hulta (1999, s. 466). Dodatkowo dopisano autorskie twierdzenie dotyczace terminowego regulowania zobowiązań wobec dostawców. Łącznie respondenci mieli do dyspozycji 20 twierdzeń, do których mieli ustosunkować się w 5-stopniowej skali Likerta, gdzie 1 oznacza „zdecydowanie nie”, a 5 - „zdecydowanie tak”.

Do pomiaru procesu przygotowania następcy na stanowisko prezesa $\mathrm{w}$ powiązaniu $\mathrm{z}$ realizacją koncepcji CSR opracowano własne twierdzenia: „Z moim następcą omawiam strategię rozwoju firmy”, „przekazuję wiedzę i doświadczenie, jak pozyskać klientów dla firmy”, „przekazuję wiedzę i doświadczenie we współpracy z kluczowymi dostawcami”, „Z moim następcą omawiam efekty firmowych programów i inicjatyw prośrodowiskowych”, „zabieram swojego następcę na spotkania $\mathrm{z}$ organizacjami charytatywnymi”. Z propozycji pomiaru procesu sukcesji autorstwa D.J. Schepkera i innych $(2018$, s. 552) zaadaptowano twierdzenie o omawianiu postępów w rozwoju następcy. Łącznie respondenci mieli do dyspozycji 6 twierdzeń oraz

Tabela 1. Rozkład wieku respondentów, ich stażu na stanowisku i stażu pracy w przedsiębiorstwie

\begin{tabular}{|l|c|c|l|c|c|l|c|c|}
\hline Wiek prezesa & $\mathbf{n}$ & $\%$ & $\begin{array}{l}\text { Staż } \\
\text { na stanowisku } \\
\text { prezesa }\end{array}$ & $\mathbf{n}$ & $\%$ & $\begin{array}{l}\text { Staż pracy } \\
\text { w przedsiębiorstwie }\end{array}$ & $\mathbf{n}$ & $\%$ \\
\hline Do 35 lat & 9 & 7,6 & Poniżej roku & 0 & 0,0 & Mniej niż 3 lata & 0 & 0,0 \\
\hline $36-45$ lat & 24 & 20,2 & $1-5$ lat & 9 & 7,6 & $3-5$ lat & 9 & 7,6 \\
\hline $46-55$ lat & 69 & 57,9 & $6-10$ lat & 55 & 46,2 & $6-10$ lat & 32 & 26,9 \\
\hline $56+$ lat & 17 & 14,3 & Powyżej 10 lat & 55 & 46,2 & Powyżej 10 lat & 78 & 65,5 \\
\hline
\end{tabular}

Źródło: opracowanie własne 
5-stopniową skalę Likerta, gdzie 1 oznacza „zdecydowanie nie”, a 5 - „zdecydowanie tak”.

\section{Wyniki badań}

B adane przedsiębiorstwa - według opinii top menedżerów - są społecznie odpowiedzialne. Średnia ocena różnych aspektów CSR wynosi 4,20 przy odchyleniu standardowym 0,10 (wartość $\min =4,0$, wartość $\max =4,65$ ). W badanych przedsiębiorstwach przestrzega się przepisów prawa, regularnie płacone są podatki, realizuje się długofalową strategię rozwoju organizacji, dba się o zadowolenie klienta i terminowe regulowanie zobowiązań wobec dostawców, wykazuje się troskę o pracowników, podejmuje się działania i programy proekologiczne. W mniejszym stopniu natomiast podejmuje się współpracę z organizacjami pozarządowymi i dba się o przyszłe pokolenia.

Istotne jest pytanie, czy proces przygotowania następcy będzie sprzyjał temu, by przedsiębiorstwo było społecznie odpowiedzialne. Pod uwagę brano następujące działania prezesa: omawianie $z$ następcą strategii rozwoju organizacji, przekazywanie wiedzy i doświadczenia w zakresie pozyskiwania klientów, przekazywanie wiedzy i doświadczenia w zakresie współpracy z kluczowymi dostawcami, angażowanie następcy w spotkania $\mathrm{z}$ organizacjami charytatywnymi, omawianie $\mathrm{z}$ następcą realizowanych w przedsiębiorstwie programów i inicjatyw prośrodowiskowych.

Dodatkowo brano pod uwagę to, czy prezes omawia $\mathrm{z}$ następcą postępy w jego rozwoju. Następcę prezesa również można traktować jako interesariusza organizacji. Zgodnie $\mathrm{z}$ definicją E. Rhenmana, interesariuszem jest także jednostka, która jest zależna od organizacji w realizacji celów osobistych i od której zależy dalsze istnienie organizacji (Strand, Freeman, 2015, s. 67). Następcą jest zwykle osoba, która aspiruje do objęcia stanowiska prezesa i kształtowania przyszłości organizacji.

W tabeli 2 zaprezentowano wyniki badań dla poszczególnych kwestii ze wskazaniem wartości średniej, odchylenia standardowego, współczynnika zmienności, wartości minimalnej i maksymalnej.

Ogólnie ujmując, w procesie przygotowania następcy obecni prezesi kładą nacisk głównie na dwie kwestie: dzielenie się wiedzą i doświadczeniem w zakresie współpracy z kluczowymi dostawcami (średnia wskazań 3,95) oraz w zakresie pozyskiwania klientów dla firmy (średnia wskazań 3,78). Najrzadziej podejmowanym działaniem jest zabieranie następcy na spotkania $z$ organizacjami pożytku publicznego (średnia 1,44). Raczej rzadko omawiają z następcą takie kwestie, jak: strategia rozwoju przedsiębiorstwa (średnia odpowiedzi 2,20) oraz programy na rzecz minimalizowania negatywnego wpływu działań przedsiębiorstwa na środowisko (średnia 2,08). Niewielu top menedżerów poświęca swój czas i uwagę na omawianie postępów w rozwoju następcy (średnia wskazań wynosi 2,45), co należy uznać za niepokojące.

Sytuacja jest zróżnicowana w poszczególnych przedsiębiorstwach, o czym świadczą współczynniki zmienności dla kwestii omawiania strategii rozwoju przedsiębiorstwa, spotkań z organizacjami charytatywnymi i troski o środowisko naturalne (tab. 2).

Wyliczono również wartości średnich dla poszczególnych przedsiębiorstw pod względem przygotowania następcy w kontekście CSR. Na tej podstawie uporządkowano przedsiębiorstwa $\mathrm{w}$ szeregu liczbowym od wartości najmniejszych do największych. W kolejnym kroku dokonano podziału na przedsiębiorstwa powyżej średniej oceny 3,0 i przedsiębiorstwa, które mają średnią ocenę co najwyżej 3,0. Liczebności grup liczą odpowiednio $\mathrm{n}=14$ i $\mathrm{n}=105$ podmiotów. Następnie dokonano szczegółowej analizy danych dotyczących praktyk w procesie przygotowania sukcesji. Na rysunku 2 zaprezentowane są dane dotyczące tych praktyk, które występują w tych dwóch grupach przedsiębiorstw.

Jak wynika z rysunku 2, w pierwszej grupie przedsiębiorstw ( $\mathrm{n}=14)$ znacznie częściej prezesi dzielą się swoim doświadczeniem $\mathrm{z}$ następcą $\mathrm{w}$ zakresie współpracy z dostawcami i pozyskiwania nowych klientów, niż ma to miejsce $\mathrm{w}$ drugiej grupie $(\mathrm{n}=105)$ przedsiębiorstw. Ponadto w co drugim przedsiębiorstwie z pierwszej grupy prezesi angażują następcę $\mathrm{w}$ proces zarządzania strategicznego, rozmawiając o obecnej i przyszłej strategii rozwoju przedsiębiorstwa. W drugiej grupie przedsiębiorstw tylko nieliczni prezesi uznają takie działanie za istotne. Wpływ przedsiębiorstwa na środowisko naturalne jest przedmiotem rozmów z następcą jedynie w 30\%

Tabela 2. Działania w procesie przygotowania następcy w kontekście CSR - wartości średniej, odchylenia standardowego, wspótczynnika zmienności, minimalna i maksymalna

\begin{tabular}{|c|c|c|c|c|c|}
\hline Wyszczególnienie & Średnia & $\begin{array}{l}\text { Odchylenie } \\
\text { standardowe }\end{array}$ & $\begin{array}{c}\text { Współczynnik } \\
\text { zmienności }\end{array}$ & Min. & $\operatorname{Max}$ \\
\hline Omawianie postępów w rozwoju następcy & 2,45 & 0,53 & 21,6 & 1 & 4 \\
\hline Omawianie strategii rozwoju przedsiębiorstwa & 2,20 & 0,96 & 43,5 & 1 & 5 \\
\hline Pozyskiwanie klientów dla przedsiębiorstwa & 3,78 & 0,62 & 16,5 & 2 & 5 \\
\hline Współpraca z kluczowymi dostawcami & 3,95 & 0,91 & 22,9 & 1 & 5 \\
\hline Spotkania z organizacjami charytatywnymi & 1,44 & 0,63 & 43,9 & 1 & 4 \\
\hline Inicjatywy i programy prośrodowiskowe & 2,08 & 0,94 & 45,1 & 1 & 5 \\
\hline
\end{tabular}

Źródło: opracowanie wtasne 


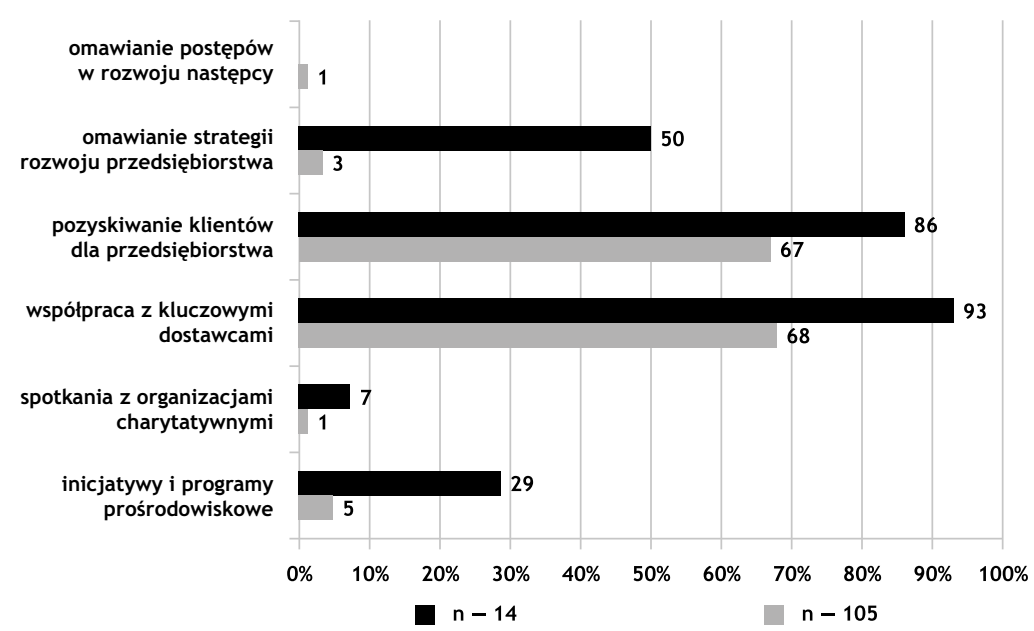

Rys. 2. Praktyki w procesie przygotowania następcy w dwóch grupach przedsiębiorstw Źródto: opracowanie własne

przypadków przedsiębiorstw z pierwszej grupy. W drugiej grupie przedsiębiorstw tylko 5\% prezesów poświęca na to czas. W każdej grupie natomiast niewielu prezesów zabiera swojego następcę na spotkania $\mathrm{z}$ organizacjami charytatywnymi. Do rzadkości należy też śledzenie przez prezesów postępów w rozwoju następcy.

Można zastanawiać się, czy w kontekście społecznej odpowiedzialności przedsiębiorstwa właściciele (założyciele) przedsiębiorstw mają inne podejście do kształtowania swojego następcy niż wynajęci menedżerowie, którym powierzono prowadzenie przedsiębiorstwa. Okazuje się jednak, że ten fakt nie ma istotnego znaczenia. Nie istnieje związek między tym, czy ktoś jest założycielem czy zatrudnionym przez właściciela menedżerem, a przygotowaniem następcy na stanowisko prezesa; test niezależności przy użyciu statystyki chi kwadrat (1) $=0,311<6,63$ dla alfa =0,01 (Aczel, 2000, s. 761). Tylko część właścicieli (tj. 13,9\% ogółu właścicieli) omawia $\mathrm{z}$ następcą nie tylko kwestie odpowiedzialności przedsiębiorstwa wobec klientów i dostawców, ale i kwestie troski o środowisko naturalne czy współpracy z organizacjami charytatywnymi.

\section{Podsumowanie}

A rtykuł prezentuje ustalenia poczynione w procesie poszukiwania odpowiedzi na pytanie badawcze, czy obecni top menedżerowie oraz założyciele (właściciele) przedsiębiorstw przygotowują następcę, który będzie kontynuował realizację idei CSR.

Badane przedsiębiorstwa - jak wynika z deklaracji zarządzających - można ocenić jako społecznie odpowiedzialne. Są w nich podejmowane działania na rzecz środowiska naturalnego, dostawców, klientów, pracowników itd. Jednak przygotowanie następcy nie łączy się $\mathrm{z}$ realizacją idei CSR w sposób kompleksowy. Podobny wniosek wynika z badań A. Lindgreena i innych (2012, s. 82).

Pozytywnie należy ocenić to, że prezesi dzielą się z następcą swoją wiedzą i doświadczeniem w zakresie kształtowania relacji $\mathrm{z}$ dostawcami i klientami. $\mathrm{W}$ odniesieniu do pozostałych interesariuszy organizacji - środowiska naturalnego i społeczności lokalnej (poprzez współpracę z organizacjami charytatywnymi) - obserwuje się mniejsze zaangażowanie prezesów $\mathrm{w}$ procesie przygotowania następcy. Również ekonomiczny wymiar CSR, z którym wiąże się omawianie strategii rozwoju przedsiębiorstwa, w praktyce nie jest zbytnio eksponowany. Trudno jest zatem mówić o kompleksowym kształtowaniu następcy pod kątem realizacji w przedsiębiorstwie koncepcji CSR. Dotyczy to zarówno top menedżerów, jak i właścicieli będących jednocześnie zarządzającymi przedsiębiorstwem. Chociaż w świetle teorii interesariuszy przedsiębiorstwo stanowi współwłasność społeczeństwa, praktyka przygotowania następcy na stanowisko prezesa takiego myślenia nie odzwierciedla.

Badania nie są wolne od ograniczeń. Badania dotyczą przede wszystkim przedsiębiorstw produkcyjnych (w małym stopniu zaś przedsiębiorstw transportowych, dobranych również ze względu na ich wpływ na środowisko naturalne), zlokalizowanych na terenie województwa mazowieckiego. Nie można więc uogólniać wyników na inne przedsiębiorstwa produkcyjne i nieprodukcyjne $\mathrm{w}$ Polsce. Ponadto $\mathrm{w}$ badaniu nie wyjaśniono, dlaczego proces przygotowania następcy nie łączy się $\mathrm{z}$ realizacją idei CSR, mimo że - jak deklarują zarządzający - przedsiębiorstwa można określić jako społecznie odpowiedzialne. W kolejnym projekcie badawczym warto byłoby poznać przyczyny braku powiązań z użyciem innych metod niż sondaż. Kolejnym ograniczeniem jest to, że źródłem opinii na temat CSR byli sami prezesi. Celem zwiększenia wiarygodności oceny społecznej odpowiedzialności przedsiębiorstwa warto byłoby pozyskać opinie od innych interesariuszy.

\footnotetext{
dr inż. Aleksandra Zaleśna Uniwersytet Jana Kochanowskiego w Kielcach Wydział Prawa i Nauk Społecznych ORCID: 0000-0003-4219-8126 e-mail: aleksandra.zalesna@ujk.edu.pl
} 


\section{Przypisy}

1) $\mathrm{W}$ przedsiębiorstwach rodzinnych sukcesja łączy się $\mathrm{z}$ przekazaniem przez założyciela następcy praw własności i kierowania przedsiębiorstwem. W procesie tym decydujący głos ma założyciel biznesu, choć możliwy jest też udział rodziny, zarządu firmy i zewnętrznych konsultantów (Sułkowski, 2012, s. 465).

2) W tego typu spółkach kandydatami na stanowiska prezesa mogą być osoby związane ze spółką lub outsiderzy - osoby z zewnątrz. Kandydaci muszą zyskać akceptację rady nadzorczej (Byrka-Kita i in., 2018, s. 24).

3) Poszczególni interesariusze mają różne oczekiwania wobec przedsiębiorstwa. Pracownicy oczekują m.in. godziwego wynagrodzenia, klienci - dobrej jakości produktów, dostawcy - terminowego regulowania zobowiązań i utrzymywania długotrwałych relacji, społeczność lokalna - wsparcia inicjatyw społecznych (np. wydarzeń kulturowych) (Masztalerz, 2014, s. 70-72; Pachciarek, Szarek, 2017, s. 295-304). Istotne jest także to, by działania przedsiębiorstwa nie powodowały dalszych szkód w środowisku naturalnym (Masztalerz, 2014, s. 72).

\section{Bibliografia}

[1] Aczel A.D. (2000), Statystyka w zarzadzaniu, Wyd. Naukowe PWN, Warszawa.

[2] Apanowicz J. (2002), Metodologia ogólna, Wydawnictwo Diecezji Pelplińskiej „Bernardinum”, Gdynia.

[3] Basu K., Palazzo G. (2008), Corporate Social Responsibility: A Process Model of Sensemaking, „Academy of Management Review", Vol. 33, No. 1, pp. 122-136.

[4] Berns K.V.D., Klarner P. (2017), A Review of the CEO Succession Literature and a Future Research Program, "Academy of Management Perspectives", Vol. 31, No. 2, pp. 83-108.

[5] Bohdziewicz P. (2014), Skuteczne planowanie sukcesji $w$ organizacji, Prace Naukowe Uniwersytetu Ekonomicznego we Wrocławiu, Nr 349, s. 45-60.

[6] Byrka-Kita K., Czerwiński M., Preś-Perepeczo A., Wiśniewski T. (2018), Zmiana na stanowisku prezesa zarzadu na polskim rynku kapitałowym, „Organizacja i Kierowanie", Nr 1, s. 11-34.

[7] Cahalane C. (2006), I Believe They Are Honourable and the Work They Do Is Honourable, „The Guardian”, https:// www.theguardian.com/business/2006/nov/03/ethicalliving.environment, access date: 1.05.2019.

[8] Frankfort-Nachmias C., Nachmias D. (2001), Metody badawcze w naukach społecznych, Wydawnictwo Zysk i S-ka, Poznań.

[9] Hamori M., Koyuncu B. (2015), Experience Matters? The Impact of Prior CEO Experience on Firm Performance, „Human Resource Management”, Vol. 54, No. 1, pp. 23-44.

[10] Janoś K. (2017), Janusz Filipiak szykuje zmianę za sterem Comarchu. Zdradza, kto przejmie firme warta prawie 2 mld $z$, https://www.money.pl/gospodarka/wiadomosci/ artykul/janusz-filipiak-comarch-sukcesja,49,0,2377521. html, data dostępu: 1.05.2019 r.
[11] Kudłak R. (2017), O przyszłości społecznej odpowiedzialności biznesu - wyniki badań europejskich, „Organizacja i Kierowanie", Nr 1, s. 71-86.

[12] Lindgreen A., Swaen V., Harness D., Hoffmann M. (2012), The Role of 'High Potentials' in Integrating and Implementing Corporate Social Responsibility, „Journal of Business Ethics", Vol. 99, No. 1, pp. 73-91.

[13] Maignan I., Ferrell O.C., Hult G.T.M. (1999), Corporate Citizenship: Cultural Antecedents and Business Benefits, "Journal of the Academy of Marketing Science", Vol. 27, No. 4, pp. 455-469.

[14] Masztalerz M. (2014), Wartość dla interesariuszy w zrównoważonym przedsiębiorstwie, „Studia Oeconomica Posnaniensia", Vol. 2, No. 8, s. 66-77.

[15] Pachciarek H., Szarek M. (2017), Kreowanie wartości dodanej dla interesariuszy - studium przypadku firmy handlowo-usługowej, „Zarządzanie i Finanse/Journal of Management and Finance", Vol. 15, No. 2, s. 293-307.

[16] Rego A., Pina e Cunha M., Polónia D. (2017), Corporate Sustainability: A View from the Top, „Journal of Business Ethics”, Vol. 143, No. 1, pp. 133-157.

[17] Reichel J. (2018), Sukcesja stanowisk kierowniczych $w$ organizacjach pozarzadowych, Wydawnictwo Uniwersytetu Łódzkiego, Łódź

[18] Rothwell W.J. (2010), Effective Succession Planning: Ensuring Leadership Continuity and Building Talent from Within, AMACOM, New York.

[19] Schepker D.J., Nyberg A.J., Ulrich M.D., Wright P.M. (2018), Planning for Future Leadership: Procedural Rationality, Formalized Succession Processes, and CEO Influence in CEO Succession Planning, "Academy of Management Journal", Vol. 61, No. 2, pp. 523-552.

[20] Strand R., Freeman R.E. (2015), Scandinavian Cooperative Advantage: The Theory and Practice of Stakeholders Engagement in Scandinavia, „Journal of Business Ethics”, Vol. 127, No. 1, pp. 65-85.

[21] Sułkowski Ł. (2012), Strategie sukcesji $w$ przedsiębiorstwach rodzinnych MŚP $w$ Polsce, Prace Naukowe Uniwersytetu Ekonomicznego we Wrocławiu, Nr 260, s. $463-473$.

[22] Szczepańska-Woszczyna K. (2018), (Nie)zmienność wartości $w$ zarzadzaniu przedsiębiorstwami rodzinnymi w procesie sukcesji i cyklu ich życia, „Przegląd Organizacji”, $\mathrm{Nr}$ 10, s. 10-17.

[23] Tang Y., Qian C., Chen G., Shen R. (2015), How CEO Hubris Affect Corporate Social (Ir)responsibility, „Strategic Management Journal", Vol. 36, No. 9, pp. 1338-1357.

[24] Turker D. (2009), Measuring Corporate Social Responsibility: A Scale Development Study, „Journal of Business Ethics", Vol. 85, No. 4, pp. 411-427.

[25] Witaszek Z. (2007), Miejsce i rola sondaży w badaniu opinii społecznej, Zeszyty Naukowe Akademii Marynarki Wojennej, Nr 4, s. 141-162.

[26] Zbierowski P. (2014), Społeczne i kulturowe aspekty sukcesu przedsiębiorstw - społeczna efektywność organizacji, Prace Naukowe Uniwersytetu Ekonomicznego we Wrocławiu, Nr 356, s. 9-18. 
Generational Succession of the Company's Management in the Context of CSR.

An Empirical Investigation in the Mazovia Voivodeship

\section{Summary}

In this paper, the author puts forward a research question whether top managers and owner-managers groom successors (future leaders) who will continue the implementation of CSR. The conducted survey included 119 companies in which the CEO succession process takes place. According to the respondents, their companies are socially responsible. However, the CEO succession process is not comprehensive in the context of CSR in the future. CEOs share their knowledge and experience with their successors when it comes to relationships with customers and suppliers. At the same time, they neglect other stakeholders. This concerns both hired managers and owner-managers.

\section{Keywords}

CEO succession, corporate social responsibility 